\title{
CAPACITY OF SOLID WASTE MANAGEMENT OF THE MUNICIPALITIES IN NORTH-WEST REGION OF BANGLADESH: A FAR CRY WITH SUSTAINABLE DEVELOPMENT
}

\author{
A K M Mahmudul Haque ${ }^{1 *}$, S M Akram Ullah², Md. Asfaq Salehin ${ }^{3}$ \\ 1,2Department of Political Science, University of Rajshahi, Rajshahi-6205, Bangladesh \\ ${ }^{3}$ Institute of Bangladesh Studies, University of Rajshahi, Rajshahi-6205, Bangladesh \\ *Corresponding Author Email: akmmahmudul@ru.ac.bd
}

\begin{abstract}
The study addresses the overall waste management and drainage system of the Municipalities of Bangladesh. It also endeavors to compare the existing system with the requirements of making a sustainable city following the targets of Sustainable Development Goals (SDG). It tries to highlight the shortcomings of the existing system of waste management and argues that this is never able to confine sustainability in the environment and the habitats of the Municipalities. The study use a qualitative approach and empirical in nature mainly based on primary data. Data have been collected from the officials and stakeholders of the three selected Municipalities of a North-west district of Bangladesh- Rajshahi through face to face interview and Focus Group Discussion. This paper identifies the fragile solid waste management capacity of the Municipalities of Bangladesh and argues that current practice is nothing but an inevitable setback for the country to achieve sustainable development.
\end{abstract}

Keywords: Capacity, Municipality, Solid Waste Management, Sustainable Development, 3Rs

\begin{abstract}
Abstrak
Studi ini membahas pengelolaan limbah secara keseluruhan dan sistem drainase di Kota Bangladesh. Selain itu juga berupaya membandingkan sistem yang ada dengan persyaratan mewujudkan kota yang berkelanjutan sesuai target Pembangunan Berkelanjutan. Penelitian ini mencoba menyoroti kekurangan dari sistem pengelolaan sampah yang ada dan berpendapat bahwa sistem ini tidak pernah dapat mengatasi masalah pengelolaan sampah berkelanjutan di lingkungan dan habitat kota. Penelitian ini menggunakan pendekatan kualitatif dan bersifat empiris terutama berdasarkan data primer. Data telah dikumpulkan dari para pejabat dan pemangku kepentingan dari tiga Kota terpilih di distrik barat laut Bangladesh-Rajshahi melalui wawancara tatap muka dan Diskusi Kelompok Terfokus. Makalah ini mengidentifikasi kapasitas pengelolaan limbah padat yang rapuh di Kotamadya Bangladesh dan menguatkan pendapat awal bahwa praktik saat ini tidak lain adalah kemunduran yang tak terelakkan bagi negara untuk mencapai pembangunan berkelanjutan.
\end{abstract}

Kata Kunci: Kapasitas, Kota, Pengelolaan Sampah, Pembangunan Berkelanjutan, 3Rs.

\section{INTRODUCTION}

Solid waste management (SWM) has been an integral part of the human society (Desa et al., 2012). Therefore, a solid waste management approach which is compatible to the nature and society is unavoidable affair for any city in this planet (Das et al., 2019). Bangladesh and its emerging towns are no exception to this. In fact, due to the gradual growth of developing nations, the rate of urbanization has reached to a certain point that it is mandatory to design and initiate a solid waste management system. Here in order to keep up the pace with the global trend and to concentrate on the sustainable development, an integrated and sustainable solid waste management system is essential incorporating 3Rs (reduce, reuse and recycle) technologies (Wilson et al., 2015). However, economic capability and other certain

* Copyright (c) 2021 A K M Mahmudul Haque et.al

This work is licensed under a $\underline{\text { Creative Commons Attribution-ShareAlike 4.0 International License. }}$

Received: December 14, 2020; In Revised: January 30, 2021; Accepted: February 12, 2021 
Khazanah Sosial, Vol. 3 No. 1 : 1 - 14

Capacity of Solid Waste Management of The Municipalities in North-West Region of Bangladesh: A Far

Cry With Sustainable Development

A K M Mahmudul Haque, S M Akram Ullah, Md. Asfaq Salehin

aspects e.g. society, culture and politics are the setbacks for countries like Bangladesh and its' towns. However, countries with greater economy like Japan and South Korea have already shown the courage of undertaking enormous projects incorporating 3Rs technologies which are highly focused on "Zero Waste" and/or "Zero Land filling" (Shekdar, 2009). According to Ahsan et al., the rate of generated waste in various cities of Bangladesh is varying within the range of 0.2 to $0.56 \mathrm{~kg} / \mathrm{cap} /$ day, meanwhile the optimum rate is $0.56 \mathrm{~kg} / \mathrm{cap} /$ day in Dhaka and the minimum waste generation rate is $0.2 \mathrm{~kg} / \mathrm{cap} /$ day in Barisal as Table 1 (Ahsan et al., 2014). The waste generation of Municipalities or in municipal areas is anticipated to a rise of $0.6 \mathrm{~kg} / \mathrm{cap} /$ day by 2025 (Islam, 2018). The waste generation rate has increased from 1.1 million tons in 1970 to 5.2 million tons in 2015 as shown in figure 1 . The trend of waste generation per year is growing at a rate of 0.1343 million tons per year ( 368 t per day). About $78 \%$ of solid waste is generated from housing sector and $20 \%$ from business sector, $1 \%$ from the institutional sector and the rest from other sectors (Ahsan et al., 2014). Existing capacity for waste management in Bangladesh varies among city corporations and municipalities, and the government authorities need immediate attention to this regard (Ray, 2008). A crucial role in improving conservancy services is taken up by community-based, private and non-government organizations as the city governments have failed to deliver the vital services (Ray, 2008).

Table 1. Total Amount of Urban Waste in Bangladesh

\begin{tabular}{|c|c|c|c|c|c|c|c|}
\hline \multirow[b]{2}{*}{ City/town } & \multirow[b]{2}{*}{$\begin{array}{c}\text { Waste } \\
\text { generation } \\
\text { rate (kg per } \\
\text { capita/day) }\end{array}$} & \multirow[b]{2}{*}{$\begin{array}{l}\text { No. } \\
\text { of } \\
\text { city }\end{array}$} & \multirow[b]{2}{*}{$\begin{array}{l}\text { Population } \\
\text { in } 2013\end{array}$} & \multicolumn{2}{|c|}{$\begin{array}{l}\text { Total waste generation } \\
\text { (tones/day) }\end{array}$} & \multirow[b]{2}{*}{$\begin{array}{l}\text { Average } \\
\text { waste } \\
\text { generation } \\
\text { (tones/day) }\end{array}$} & \multirow[b]{2}{*}{$\begin{array}{c}\text { Average } \\
\text { waste } \\
\text { generation } \\
\text { (tones/year) }\end{array}$} \\
\hline & & & & Dry season & $\begin{array}{l}\text { Wet season } \\
\quad(46 \% \\
\text { increase } \\
\text { from dry } \\
\text { season) }\end{array}$ & & \\
\hline Dhaka & 0.56 & 1 & $72,27,891$ & $4,047.62$ & $5,909.52$ & $4,978.57$ & $18,17,179$ \\
\hline Chittagong & 0.48 & 1 & $26,56,472$ & $1,275.11$ & $1,568.38$ & $1,568.38$ & $5,72,459$ \\
\hline Khulna & 0.27 & 1 & $6,73,093$ & 181.74 & 265.33 & 223.53 & 81,590 \\
\hline Rajshahi & 0.44 & 1 & $4,56,277$ & 200.76 & 293.11 & 246.94 & 90,132 \\
\hline Barishal & 0.25 & 1 & $3,45,972$ & 86.49 & 126.28 & 106.39 & 38,831 \\
\hline Sylhet & 0.3 & 1 & $5,09,107$ & 152.73 & 222.99 & 187.86 & 68,569 \\
\hline Municipalities & 0.25 & 308 & $1,93,63,662$ & $4,840.92$ & $7,067.74$ & $5,954.33$ & $21,73,329$ \\
\hline $\begin{array}{l}\text { Other Urban } \\
\text { Centers }\end{array}$ & 0.15 & 208 & $57,54,294$ & 863.14 & $1,260.19$ & $1,061.67$ & $3,87,509$ \\
\hline Total & & 522 & $36,98,67,68$ & $11,584.63$ & $16,913.56$ & $14,249.09$ & $52,00,919$ \\
\hline
\end{tabular}

Source: Ahsan et al (2014)

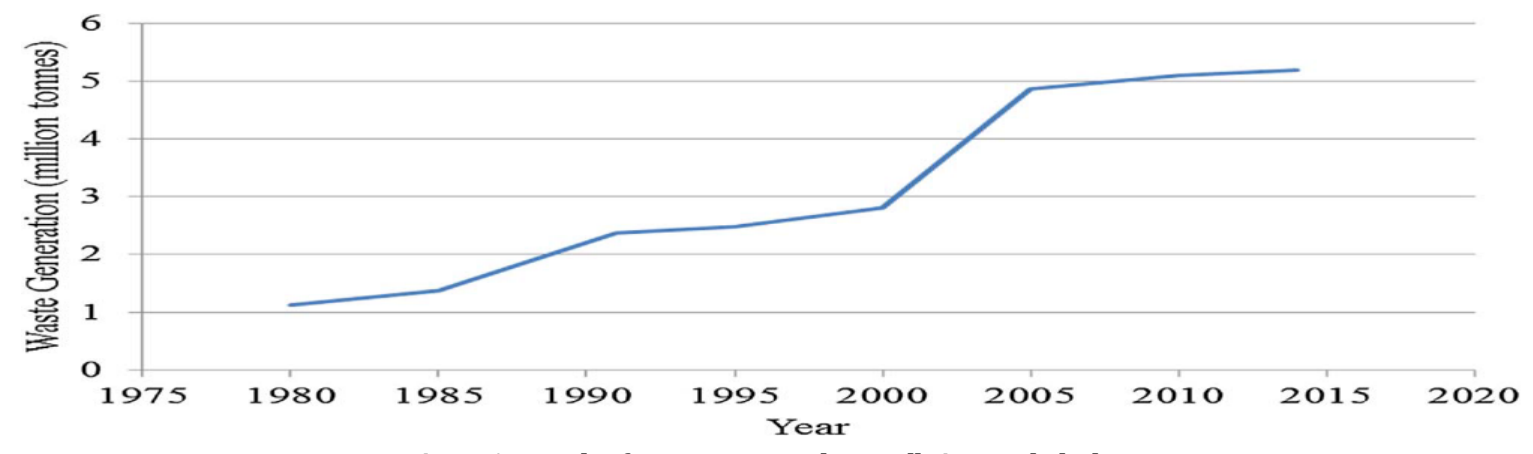

Figure 1. Trends of waste generated annually in Bangladesh. Source: Adopted from Ahsan et al (2014) 
Khazanah Sosial, Vol. 3 No. 1 : 1 - 14

Capacity of Solid Waste Management of The Municipalities in North-West Region of Bangladesh: A Far

Cry With Sustainable Development

A K M Mahmudul Haque, S M Akram Ullah, Md. Asfaq Salehin

In this circumstance, the 330 Municipalities of Bangladesh are confronting the challenge of taking care of the daily produced waste with a very poorly equipped system. As a consequence, the existing waste management system of Bangladesh totally mismatches the required system which is compatible with Sustainable Development Goals. Several previous studies such as research Alam \& Qiao (2020), Ashikuzzaman \& Howlader (2020) and Dey et al (2020) however, research on sustainable waste management systems is lacking. This paper assessed the waste management system of three town governing agencies and compared it to the system that is required to be sustainable solid waste management system.

\section{RESEARCH METHOD}

This paper is constructed on both qualitative and quantitative data. Quantitative data have been gathered mostly from secondary sources namely, online materials, newspaper features, articles, books and other relevant supplements (Brannen, 2017). For primary data, mostly three municipalities of Rajshahi district named Katakhali, Naohata and Puthia have been chosen. Nine officials from three municipalities (three from each) have been interviewed along with the 300 local residents ( 100 from each municipality). In order to collect data, questionnaire survey was applied as a tool where two sets of questionnaire were developed, one for the municipality officials and another for the local residents.

Three FGDs have also been conducted in three selected municipalities. Each FGD was conducted inviting eight members from each municipality considering their knowledge and expertise in local solid waste management issues. FGD members were chosen from different professions such as, local influential persons, locally renowned business men, teachers, public representatives, etc (Mishra, 2016). A check list was made incorporating four agenda of solid waste management which were set by congesting the homogenous questions from the questionnaire. The FGD was moderated and opinions were recorded by two separated individuals. Each of the members was well participatory and cooperative and their statements were found highly efficient by which cross check with the findings of the field survey has been done in order to understand their final opinion.

\section{RESULTS AND DISCUSSION \\ CONCEPT OF SOLID WASTE MANAGEMENT}

The word 'waste' refers to useless, unwanted or discarded materials, which are no longer considered of sufficient value and are thrown away by the possessor. Waste means any solid, liquid, gaseous, radioactive substance, the discharge, disposal and dumping of things which may cause harmful change to the environment (Hossain et al., 2011). On the other hand, solid waste is the pile of dirt and filth. It is the resultant of the utilization of products by the consumers. Solid wastes comprise of all solid refuses or trashes resulting from the normal activities of the community except excreta (Gautam \& Agrawal, 2021; Sutrisno, 2017). In Agenda 21 of Rio Earth Summit in 1992, solid waste has been defined as all domestic and non-hazardous wastes, such as, commercial and institutional waste, street sweeping and constructional debris (Joseph, 2014). Municipal solid wastes are generally viewed as a municipal responsibility, includes: household garbage and rubbish, residential ashes, commercial refuse, institutional refuse, street sweepings, construction and demolition debris, dead animals, sanitation residue, industrial, clinical and hospitals wastes. Household waste is mainly composed of food, grass and plants, brick, dirt, paper and polythene, shredded skin, leather etc. 
Khazanah Sosial, Vol. 3 No. 1 : 1 - 14

Capacity of Solid Waste Management of The Municipalities in North-West Region of Bangladesh: A Far

Cry With Sustainable Development

A K M Mahmudul Haque, S M Akram Ullah, Md. Asfaq Salehin

Solid waste management refers to the management of solid garbage. Management is a process of planning, organizing, directing, controlling, and coordinating for attaining a common goal. On the other hand, solid waste management is a methodology of minimization of wastes, primarily through reduction at source, but also including recycling and re-use of materials and final disposal. It is the systemic administration of activities for the collection, source separation, storage, transportation, transfer, processing, treatment and disposal of solid wastes (Tai et al., 2011). It is a process of handling wastes (collection and transportation) through minimum cost targeting reduction at source, re-use and recycling and final disposal with least pollution for achieving a sustainable environmental development.

Sustainable management of solid waste addresses public health, environmental pollution, land use, resource management and socio-economic impacts associated with improper disposal of waste (Marshall \& Farahbakhsh, 2013). Sustainable waste management reduces the amount of natural resources consumed, confirms that any materials that are taken from nature are reused as many times as possible and that the waste created is kept to a minimum.

Sustainable solid waste management is a more efficient and environment friendly way that deals with the wastes generated daily. Although, the concept varies from country to country, there are a few core components. Firstly, sustainable waste management system is effective to reduce the generation of wastes gradually. Secondly, generated wastes must be separated before dumping. This separation should be done twice; firstly in the household, then by the municipality before dumping. Different types of strategy are applied to treat the wastes. Following this method, 3Rs (Reduce, Reuse and Recycle) technique should be applied. In addition, a sustainable waste management must incorporate sophisticated treatment plant, policies, and laws for waste management (Shekdar, 2009). Sustainable solid waste management can be conceptualized in the figure 2 .

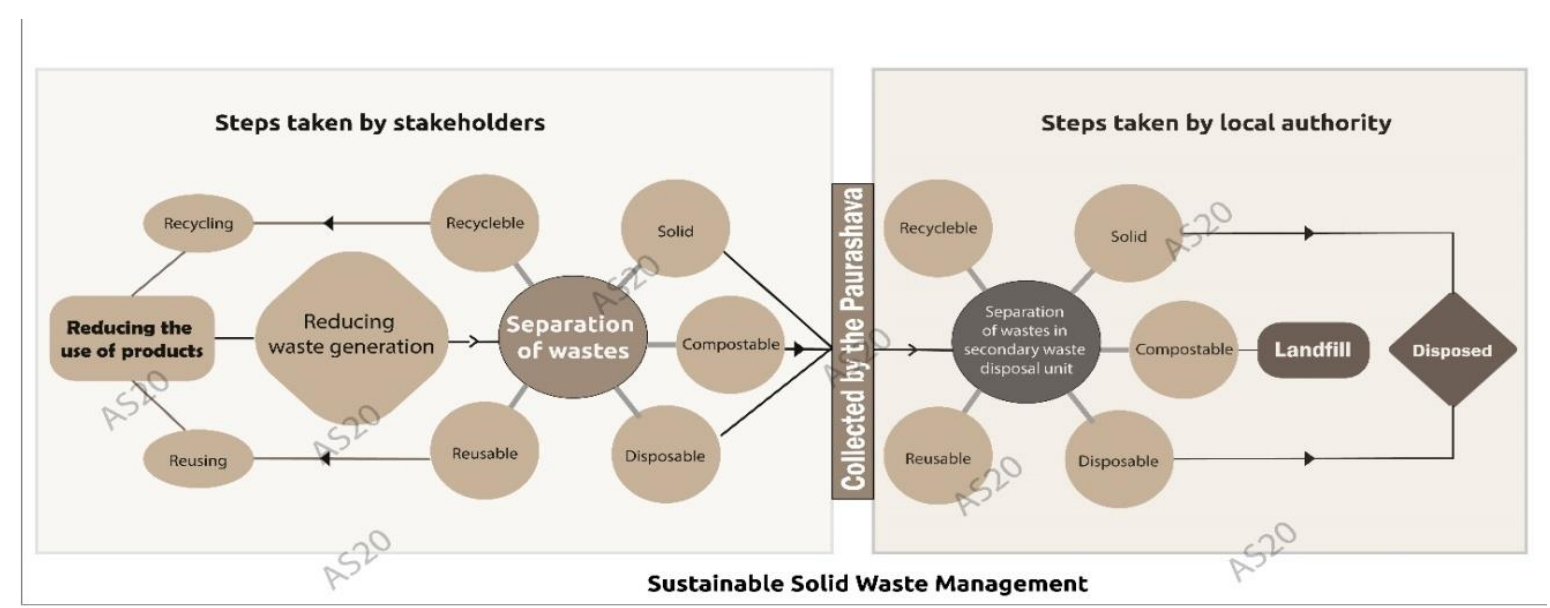

Figure 2. Sustainable Solid Waste Management

Source: Developed by the researchers (2020)

\section{Results}

Regarding waste management practices, chief officials of all the selected Municipalities were asked several questions. Table 2, Table 3 and Table 4 have been arranged on the basis of information given by the concerned officials of Katakhali, Puthia and Naohata Municipality. 
Khazanah Sosial, Vol. 3 No. 1 : 1 - 14

Capacity of Solid Waste Management of The Municipalities in North-West Region of Bangladesh: A Far

Cry With Sustainable Development

A K M Mahmudul Haque, S M Akram Ullah, Md. Asfaq Salehin

The study reveals that Katakhali Municipality does not have any dumping station to dump its wastes. In this case, its responsible workers throw away their collected wastes in the river Padma which is 4km away from the city. The way taken by Katakhali Municipality to dump collected wastes in the Padma does not bring any positive impact in the city area and in the environment rather it threatens the environment seriously. One of the researchers asked a question to the local body about their particular plans for the future. In response of this question, the local body responded positively and said that Katakhali Municipality has been selected for a project named 'Water and Sanitation Program' funded by the World Bank. This international financial organization has selected 30 Municipalities across the country under the project of 'Water and Sanitation Program.' In the words of Secretary of Katakhali Paurashava,

"Currently, there is no other options in our hand. We are waiting. We have already selected a land for making a garbage pit, we are also hoping that, we will install a well-equipped garbage management system with all the modern technologies. There will also be a treatment plant and a disposal unit as well. We have been being optimistic since getting a roll of entries by the World Bank for this project. The World Bank will distribute 870 million BDT among 30 Municipalities across the country. Our Municipality has done well in view of its standing committee meeting, and we have reported the overall progress in black and white to the Ward Level Coordination Committee (WLCC) and Town Level Coordination Committee (TLCC). Our consistent progress has awarded us with this project (Personal Communication with Munir, A K M Mahmudul Haque, July 17 2019)".

Therefore, solid waste management of Katakhali Municipality to a great extent is depended on the project to be started later. In case of solid waste management, the situation and capacity of Naohata Municipality is not better than that of Katakhali Municipality. It does not have any specific place except a land (pit) to dump its wastes inside the city. Chief Official of Naohata Municipality informs us that they sometimes throw away the solid wastes to fill some ponds or low land of local inhabitants on the basis of their consent. However, no specific area is used as a garbage pit. FGD respondents also mention that, there is no pit in their Municipality. The situation is so poor that, it is not rational to expect any treatment plant or any composting system. They consider the environmental issues so poorly that they do not find any way out for assessing environmental issues properly.

Table 2. Core Issues of Solid Waste Management

\begin{tabular}{llll}
\hline Core Issues of Waste Management & Katakhali & Naohata & Puthia \\
\hline Dumping Station & $\begin{array}{l}\text { Dumps the entire wastes in } \\
\text { the River Padma }\end{array}$ & $\begin{array}{l}\text { Dumps in the land } \\
\text { (Public Property) }\end{array}$ & By the main road \\
Distance of dumping station from the city & $4 \mathrm{~km}$ & Inside the town & Yes \\
Local residence around & No & 0.27 Hector & No \\
Area & N/A & No & No \\
Treatment plan & No & No & No \\
Composting system & No & Never & Never \\
Environmental and Social Impact Assessment & Never & \\
\hline
\end{tabular}

Source: Field Survey, 2019

Table 3 depicts the solid waste management capacity of the Katakhali, Puthia and Naohata Municipality. In case of Katakhali Municipality, it has two dump trucks and three paddle vans. But, the situation is totally different subject to consideration of the number of personnel. The authority of Katakhali Municipality claims that they have twenty six field staff working in the city under 'no work no pay' basis for managing the wastes. Even, there is no specialized person to monitor or supervise the waste management procedure. But the report of FGD and observation revealed a different story. FGD members 
Khazanah Sosial, Vol. 3 No. 1 : 1 - 14

Capacity of Solid Waste Management of The Municipalities in North-West Region of Bangladesh: A Far Cry With Sustainable Development

A K M Mahmudul Haque, S M Akram Ullah, Md. Asfaq Salehin

failed to recall any sort of cleaning activities of the Municipality except in the main road and the Bazar. About instruments, they are lagging far behind and they do not think that they have enough personnel either. However, twenty six field staff for a Municipality like Katakhali sounds fair and manageable. This Municipality also does not keep any record of the amount of daily waste generation. About infrastructural sufficiency, Katakhali Municipality authority claims that they have about 50 dustbins across the Municipality but the FGD report and physical observation prove that the claim of Municipality authority is completely different from the real picture and the number of the dustbins that exist in the Municipality area is not same as the claimed number of the authority.

In the city area, scavengers play an important role to collect wastes and to keep the city neat and clean. The local authority may maintain contact with them (Asim et al., 2012). However, Katakhali Municipality does not keep record of any scavengers. When the local authority was asked about the frequency of cleaning the road of the Municipality area, they gave negative answers. The report of FGD was also same in this case. According to FGD report, the Municipality only sweeps the main road and a few places of the markets. Even the market places, now and then, are cleaned by the markets' own attempt. In fact, the role of the local authority is hardly noticeable in terms of waste management.

In case of Naohata, the situation was not different. It was almost as same as Katakhali Municipality. It also owns three paddle vans and two garbage trucks. This Municipality has a person to monitor and inspect the overall waste management process. The person who is in charge of supervising the waste management system of the area informed us. We want to provide good services for the citizen but realities do not let us do anything. Political pressure is more than what we expect necessary here. The Mayor always wants to keep his popularity on the top. Therefore, he lets his followers do anything what they want. Many initiatives of the Municipality do not see the light of the day. Most of the people don't pay any heed to our indications. On the contrary, they take a side on the part of the Mayor. Our Municipality generates huge revenue; we have a lot of services to offer the citizens. If the workers and members of this local governing body unify themselves, then the scenario will be different (Personal Communication with Mostak, Asfaq Salehin, July 19, 2019).

The information provided by the official of Katakhali Municipality seems to be true, if findings of the FGD are found identical. According to the report, there is no waste management system in this area. No one collect the waste from the household or other local places. Most of the places of the Municipality except the roadside are still rural. Dwellers take care of their own wastes. A little amount of wastes managed by the sweepers from the market places and the main road sides is thrown away to pile here and there. Therefore, these places become dirty instead of making the city clean, the Municipality makes it even worse. One of the FGD members claimed that he had got one personnel red-handed while he was throwing the garbage in the river. The responses from the official and the findings from the city are highly depressing. The waste management system of these two local bodies is poor and indicates to very poor environmental governance as well.

Table 3 shows that the waste management system of Puthia Municipality is very much fragile. Not unlikely Katakhali and Naohata Municipality, Puthia Municipality does not have any solid waste management system as well. In some cases, it seems more vulnerable. Especially, the capacity of Puthia is weaker than the other two. Besides this, about treatment plant, composting system, Environmental and Social Impact Assessment, Puthia Municipality has not taken any initiative as well. While asking about the overall waste management system of Puthia Municipality, one of its high officials (Engineer) informed us that, 
Khazanah Sosial, Vol. 3 No. 1 : 1 - 14

Capacity of Solid Waste Management of The Municipalities in North-West Region of Bangladesh: A Far

Cry With Sustainable Development

A K M Mahmudul Haque, S M Akram Ullah, Md. Asfaq Salehin

Puthia is comparatively a small and weak Municipality. There is hardly any modern facility. The income of Puthia Municipality is too poor to build a strong fund for each sector. Our Municipality is delivering the basic services in a traditional way. In terms of introducing a system for managing the solid wastes of the town, we have not planned anything particularly. As you see, our Municipality does not even have any convenient office as well. The biggest problem is that Puthia Municipality does not have any spare land inside the town that can be used to improve the service delivery (Personal Communication with Saiful, S M Akram Ullah, July 21, 2019).

Therefore, overall waste management system of the three selected Municipalities is equally vulnerable and hardly qualified as a sustainable solid waste management system. Table 4 also indicates the vulnerability of the systems as well. It indicates that Katakhali, Puthia and Naohata uphold almost same capability in transporting waste because all of them have equal number of vehicles. On the other hand, Puthia seems weaker having a truck and a van less than the other two. In terms of manpower, Katakhali is more capable rather than Naohata and Puthia. The later two Municipalities are weaker because they do not have any specific set of personnel for this task. Further information of the table clarifies that the waste management system of three selected areas is weak. However, Katakhali has a future plan over this crisis. But the other two do not seem to have anything for the future regarding this service delivery. In response to the question about regular inspection on solid waste management activities, the respondents of Naohata Municipality, especially the member of authoritative body told that they inspect the activities positively. But the findings and responses of FGD composed of stakeholders gave us different opinion and that was completely opposite to the answers given by the member of authoritative body of Naohata Municipality.

Table 3. Solid Waste Management Capacity of the Municipalities

\begin{tabular}{|c|c|c|c|}
\hline Waste Management Capacity & Katakhali & Naohata & Puthia \\
\hline Waste Transporting Vehicles & $\begin{array}{l}3 \text { Vans and } 2 \text { Dump } \\
\text { Trucks }\end{array}$ & $\begin{array}{l}3 \text { Vans and } 2 \text { Dump } \\
\text { Trucks }\end{array}$ & 2 Vans 1 Dum Trucks \\
\hline Cleaning personnel & 26 & 6 & Not Specific \\
\hline Cleaning personnel type & No work no pay & No work no pay & No work no pay \\
\hline Authority to inspect & No & Yes & Never \\
\hline Amount of daily waste & $\mathrm{N} / \mathrm{A}$ & $\mathrm{N} / \mathrm{A}$ & $\mathrm{N} / \mathrm{A}$ \\
\hline Workers use safety equipment & No & No & No \\
\hline $\begin{array}{l}\text { Sufficiency of labor and equipment to collect } \\
\text { waste }\end{array}$ & Not sufficient at all & Not sufficient at all & Not sufficient at all \\
\hline Infrastructural sufficiency (Dustbins) & Not sufficient at all & Not sufficient at all & Not sufficient at all \\
\hline Regular inspection & No & No & No \\
\hline Contact to the scavengers & No & No & Not any \\
\hline Cleaning the road regularly & No & Occasionally & Yes \\
\hline Sufficiency of vehicles for collecting waste & No & No & No \\
\hline
\end{tabular}

Source: Field Survey (2019)

Looking further at the waste management system of these three Municipalities, then the researchers have got discomforting and troublesome data. All regions have ensured that, they do not have specific measures for collecting waste from different institutes like hospitals and clinics, hotels, restaurants 
Khazanah Sosial, Vol. 3 No. 1 : 1 - 14

Capacity of Solid Waste Management of The Municipalities in North-West Region of Bangladesh: A Far Cry With Sustainable Development

A K M Mahmudul Haque, S M Akram Ullah, Md. Asfaq Salehin

and households. However, one of the respondents of Katakhali Municipality has ensured that the butchers' shop is well taken care of. The report of FGD and observation reveals that the Municipality authority has nothing to do in the sphere of collecting solid waste from the butchers' shops. It does not play any role to clean up the butchers' shops carefully. Actually, all butchers' shops are taken care of by the shops' owners. They do it only for their own interests. We all know that wastes from the hospitals might be hazardous and injurious for health. Therefore, these wastes should be shifted regularly by the Municipality authority. But nothing of that is done in Katakhali Municipality. In this case, one of the officials from Katakhali Municipality expressed that the clinics do not give us a satisfactory amount of taxes. Therefore, we do not provide them any special service in return. Their wastes should be managed by themselves (Personal Communication with Shamim Ashraful, A K M Mahmudul Haque, July 17, 2019).

The officials from Naohata Municipality and stakeholders were also asked about the same issue. Data collected from the field level prove that the respondents do not have much knowledge about hazardous and non-hazardous garbages. The FGDs report also ensured that no special measure is taken by the authority for managing wastes produced from hospitals and clinics, hotels, restaurants, butchers' shop, and the like. Even in this area, they do not have any step to clean the markets as well. The markets are cleaned and the wastes are managed by their own workers, not by the workers of Municipality.

In Katakhali Municipality, twenty six workers are engaged to clean the drains on a regular basis. Though the authority claims that they clean the drains frequently, the report of FGD and field observation didn't find this statement true. In the Municipality area, there is no concrete drain inside the town. In case of Naohata Municipality, the situation is still worse in amount and quality. Although, there are a few concrete drains but all of them are built in an unplanned way. So, it turns out more like a curse than a blessing. Even there is no option of the drains to take the liquid waste to any suitable place out of the locality. All of the dirty liquid wastes are absorbed by the soil and the environment gets even more affected by the liquid waste. About this issue, the local authority said,

The Municipality has the capacity to construct an effective drainage system but the political issue is the biggest drawback in this case. The leaders who want to be more popular in this region patronize the local people in a negative way. Most of these citizens don't let the authority to use their land for or build the drains. The local authority faces such a type of problems when they want to construct dustbins. Therefore, it is possible on the part of them to ensure environmental good governance in this region to some extent but the political impediment has become a great challenge in the way of ensuring environmental good governance (Personal Communicatiom with Mesbah, A K M Mahmudul Haque, January 19, 2020).

About the industrial wastes, the Municipalities have let us know that, the industries highly pollute the environment. But they don't take any special care for the industrial wastes. Most of the industries release their liquid waste in the central raw drain and the canal. And some of them leave a portion of the liquid in an open low land. As a result, it pollutes the environment and daily life and it invites human being to face a big difficult challenge. The local citizens are highly bothered for this action of the industries. Initiative taken in this regard was very passive and the Municipalities were not found interested to resolve this crisis.

One of the responsibilities of the Municipality is to supply health risk-reducing materials, like uniform, gumboots, masks, hand gloves, etc. for its conservancy workers. During interview and field observation, it is found that workers of every selected Municipality do not use safety materials while they are cleaning or sweeping roads, drains, tips, etc. Municipality officials said that they provide health riskreducing materials, sufficient training and necessary treatment to their conservancy workers. But the 
Khazanah Sosial, Vol. 3 No. 1 : 1 - 14

Capacity of Solid Waste Management of The Municipalities in North-West Region of Bangladesh: A Far

Cry With Sustainable Development

A K M Mahmudul Haque, S M Akram Ullah, Md. Asfaq Salehin

workers do not use these safety materials because of their limited knowledge and lack of awareness. Many workers do not participate in the training sessions, giving false excuses. The Municipality does not take any punitive measures for such workers as well.

Table 4. Managing the Solid Waste

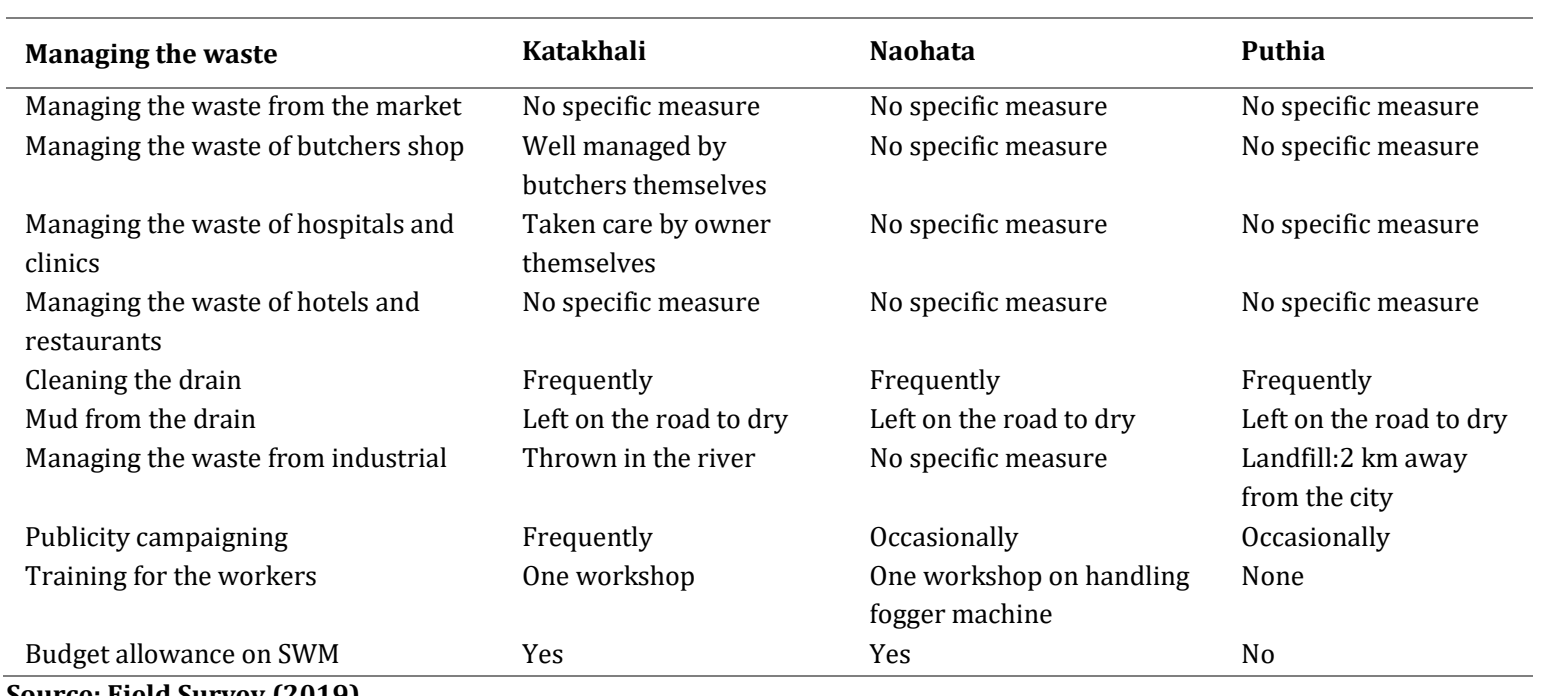

Source: Field Survey (2019)

As a part of ensuring sustainable waste management, the Municipalities must create awareness programs on waste management issues and continue the publicity or campaigning regarding the cleanliness and garbage management. But each of Katakhali, Naohata and Puthia Municipality was found regardless in this issue. The authorities said that they have done a few time to time. But the field report and FGD proved the claims of authority false. Every respondent agreed that there is a lack of budgets and plans for this issue (Rodić \& Wilson, 2017).

Mismanagement of solid waste has a great adverse impact that pollutes environment to a great extent and creates health hazard (Ferronato \& Torretta, 2019; Malav et al., 2020). Data (presented below) have been collected from the respondents to extract further information regarding the solid waste management system of these three Municipalities. Data arranged in Table 5 draws a clear picture about the overall situation and problems of solid waste management of each of the Municipalities. The Table 5 has been made after a proper investigation. One of the biggest problems for which Municipalities suffer a lot in proper managing of solid waste and keeping the drainage system clean is that, throwing the wastes in the drains is a common tendency of residents of every region. On the other hand, more than half (53.66\%) of the respondents also claimed that, the authorities do not remove the waste in time on account of their apathy. Local cooperation is also absent, and this is confessed by $63.33 \%$ of the total respondents. Over and above this, $84 \%$ of the total respondents think that the Municipality authorities are responsible for ruling a clean town and its solid waste management system. But it is obvious that there is a lack of responsibility of the Municipality authorities in this sphere. $41 \%$ of the total respondents traced the faulty drainage system as one of the key problems of solid waste management and they think that drains of the town are not managed properly. $42.66 \%$ identified lack of conservancy staff, $27.66 \%$ marked off lack of dustbins, $46.66 \%$ traced lack of equipments and $60.66 \%$ branded lack of budget as the key problems of sustainable solid waste management system and they are dissatisfied with these problems. 
Khazanah Sosial, Vol. 3 No. 1 : 1 - 14

Capacity of Solid Waste Management of The Municipalities in North-West Region of Bangladesh: A Far

Cry With Sustainable Development

A K M Mahmudul Haque, S M Akram Ullah, Md. Asfaq Salehin

Table 5. Key Problems of Solid Waste Management

\begin{tabular}{lllll}
\hline Key problems of waste management & Katakhali & Naohata & Puthia & Average (\%) \\
\hline Dumping waste in the drains & $100 \%$ & $100 \%$ & $100 \%$ & $100 \%$ \\
Apathy in removing waste in time & $44 \%$ & $65 \%$ & $52 \%$ & $53.66 \%$ \\
Lack of local cooperation & $18 \%$ & $80 \%$ & $92 \%$ & $63.33 \%$ \\
Lack of authority's responsibility & $77 \%$ & $81 \%$ & $94 \%$ & $84 \%$ \\
Lack of conservancy staff & $28 \%$ & $22 \%$ & $78 \%$ & $42.66 \%$ \\
Lack of dustbins & $10 \%$ & $13 \%$ & $60 \%$ & $27.66 \%$ \\
Lack of equipment & $64 \%$ & $53 \%$ & $23 \%$ & $46.66 \%$ \\
Faulty drainage system & $18 \%$ & $69 \%$ & $36 \%$ & $41 \%$ \\
Lack of budget & $73 \%$ & $26 \%$ & $83 \%$ & $60.66 \%$ \\
\hline
\end{tabular}

Source: Field Survey (2019)

Infrastructural supports and facilities are very essential for ensuring sustainable solid waste management. But field survey (Table 6) reveals that more than half (57.66\%) of the respondents on an average from each of the three Municipalities identified infrastructural problems of local authority as the worst constraint in managing solid wastes sustainably.

Table 6. Infrastructural Problems in Managing Solid Waste

\begin{tabular}{llll}
\hline Infrastructural problems in managing solid waste & Yes & No & No Comments \\
\hline Katakhali Municipality & $67(67 \%)$ & $04(04 \%)$ & $29(29 \%)$ \\
Naohata Municipality & $36(36 \%)$ & $06(06 \%)$ & $58(58 \%)$ \\
Puthia Municipality & $70(70 \%)$ & $05(05 \%)$ & $25(25 \%)$ \\
Average (\%) & $57.66 \%$ & $05(05 \%)$ & $37.33 \%$ \\
\hline
\end{tabular}

Source: Field Survey (2019)

On the basis of data collected by the field study and arrayed in the Table 6, it can be said that $63 \%$ of the respondents believe the weak solid waste management system of their Municipality is posing a threat on the health of the local residents whereas $84.33 \%$ admit that it is more threatening to the environment as well. Only $08 \%$ of the total respondents do not consider this as an issue at all.

\section{Disscusion}

\section{A FAR CRY WITH SUSTAINABLE DEVELOPMENT}

Generally Bangladesh shares almost same and homogenous characteristics in most of its regions both culturally and socially. Therefore the findings of this study might be a general picture for all the underdeveloped Municipalities of the country. 


\section{Khazanah Sosial, Vol. 3 No. 1 : 1 - 14}

Capacity of Solid Waste Management of The Municipalities in North-West Region of Bangladesh: A Far Cry With Sustainable Development

A K M Mahmudul Haque, S M Akram Ullah, Md. Asfaq Salehin

\begin{tabular}{|c|c|c|c|c|c|}
\hline \multirow{4}{*}{ 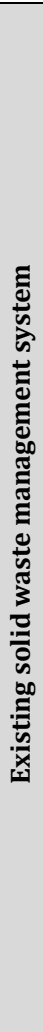 } & $\begin{array}{l}\text { Major } \\
\text { Findings }\end{array}$ & $\begin{array}{l}\text { Katakhali } \\
\text { Municipality }\end{array}$ & $\begin{array}{l}\text { Naohata } \\
\text { Municipality }\end{array}$ & $\begin{array}{l}\text { Puthia } \\
\text { Municipality }\end{array}$ & $\begin{array}{c}\text { Responsible } \\
\text { Institutions }\end{array}$ \\
\hline & 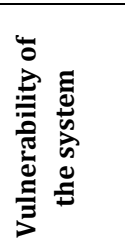 & $\begin{array}{ll} & \text { Insufficient equipment } \\
\text { - } & \text { No secondary waste disposal units } \\
\text { - } & \text { Shortage of staff } \\
\text { - } & \text { No written policies } \\
& \text { Noture plans (Except Katakhali) }\end{array}$ & Indifferent & Indifferent & \multirow{3}{*}{ 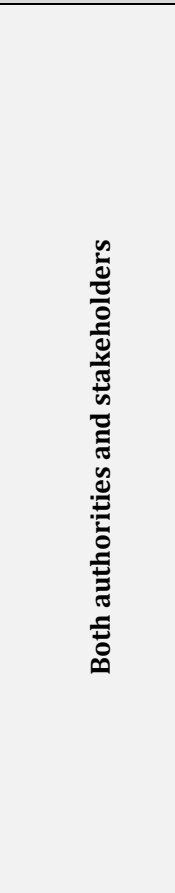 } \\
\hline & 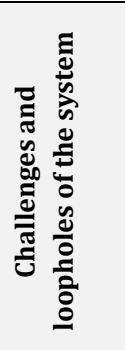 & $\begin{array}{ll}\text { - } & \text { Insufficient Budget } \\
\text { - } & \text { Lack of awareness } \\
& \text { Lack of central government } \\
\text { intervention } \\
\text { - } & \text { Lack of stakeholders' cooperation } \\
\text { - } & \text { No specific policy } \\
\text { - } & \text { Political intervention }\end{array}$ & Indifferent & Indifferent & \\
\hline & 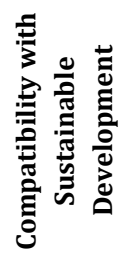 & \multicolumn{3}{|c|}{ Not Compatible } & \\
\hline
\end{tabular}

Source: Developed by the researchers (2020)

In this sense, the circumstance looks more threatening. The discussion of the previous section and table 7 completely sums up the vulnerability and irregularity in the existing solid waste management system.

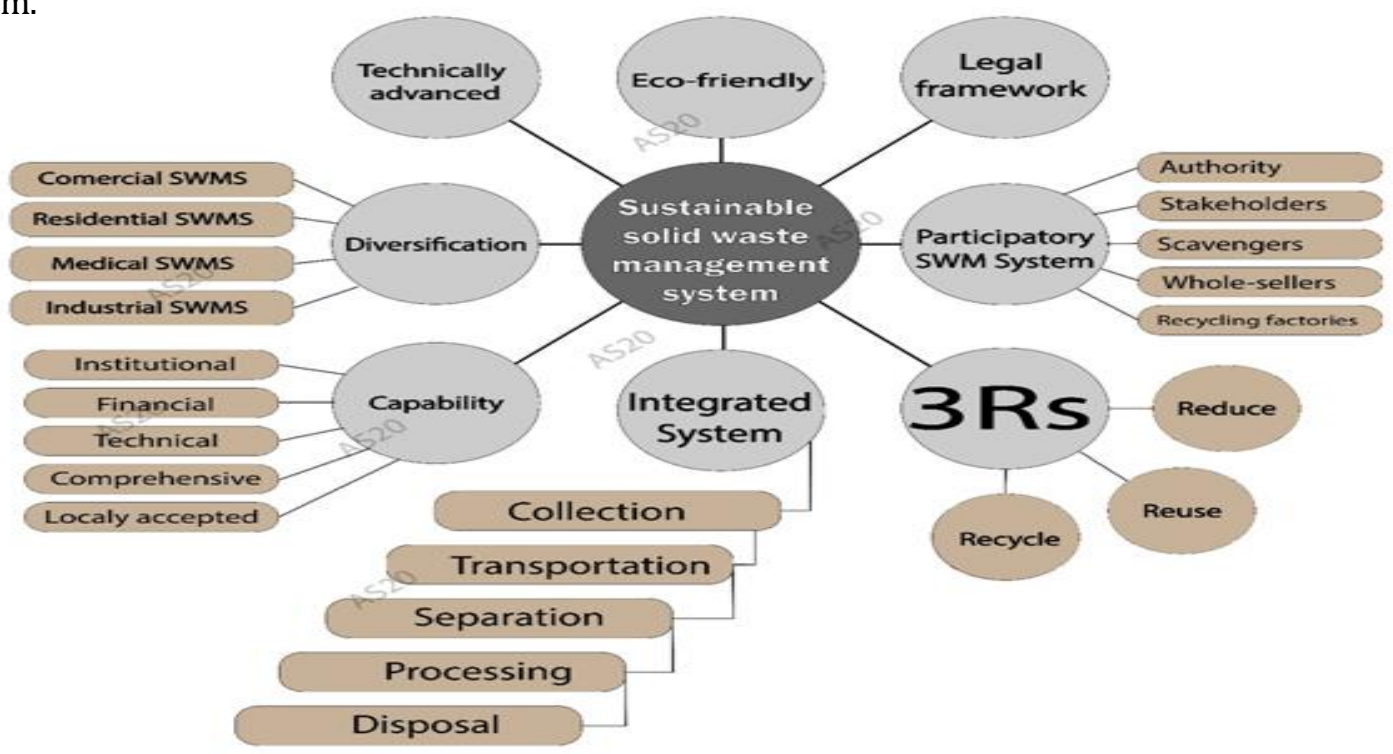

Figure 3. Desired Waste Management System for the Municipalities

Source: Developed by the researchers (2020) 
Khazanah Sosial, Vol. 3 No. 1 : 1 - 14

Capacity of Solid Waste Management of The Municipalities in North-West Region of Bangladesh: A Far

Cry With Sustainable Development

A K M Mahmudul Haque, S M Akram Ullah, Md. Asfaq Salehin

The attributes mentioned in Figure 3 will clarify the position of the existing situation. Where it says diversification is necessary in all the places, like, commercial, industrial, household, hospital etc. but yet it is not in practice. Talking of an integrated waste management system ensuring proper collection, transportation, separation, processing, and disposal nothing is conducting accordingly (de Oliveira et al., 2012). On the other hand, where a sustainable solid waste management system should be cooperative of participatory ensuring active participation of authorities, stakeholders, scavengers, wholesalers, recycling factory but in this case these are completely absent. At last, ensuring 3Rs in every town and cities in order to achieve, zero waste, zero pollution and zero landfill seems completely impossible unless the following measures are taken,

1. Necessity of framing strict and efficient policies for sustainable management of urban solid waste is essential;

2. Government must patronize the local authorities in this issue;

3. Local authorities must be brought under a regulation and should be given targets to make them more serious in this regard;

4. Implication of environmental laws should be enforced;

5. Land should be allocated for each of the three Municipalities as soon as possible for dumping of the solid waste sustainably;

6. Solid waste management system must be integrated with efficient collection, transportation, separation, processing and disposal system;

7. Participation and interaction among authorities, stakeholders, scavengers, whole-seller shops, recycling shops must be ensured.

8. Financial, institutional and technical capabilities of each Municipality should be increased;

9. Different waste management strategies should be devised and designed for managing residential, commercial, industrial and medical wastes.

\section{CONCLUSION}

With the emergence of human civilization, the authorities from highest level to lowest level, government and non-government organizations, planners and residents, all have to be more conscious, efficient and competent and seriously sensible to tackle the challenges yet to come. The good consequences, pleasant and embellish future of human being are almost depended on the noble will of the people's representatives i. e. politicians, authorities, related government and non-government organizations and the conscious citizens of a country. But in most cases, it is seen and proved that some causes harm our clean and clear favorite environment. It affects human being severely with huge cost. We can get rid of danger of environmental degradation only by implementing the Sustainable Development Goals (SDGs) as the part of our policies. The success of SDG 11 pertaining sustainable cities and communities depends on some important factors. One of the important factors is sustainable waste management system. The introduction of SDGs and giving extreme priority in every sphere of environment is enough to make us understand the importance of sustainable solid waste management for making a habitable town or city. Following a planned way, managing solid wastes of Municipalities can be effective for developing sustainable management of urban solid wastes from both environmental and economic perspectives. 
Khazanah Sosial, Vol. 3 No. 1 : 1 - 14

Capacity of Solid Waste Management of The Municipalities in North-West Region of Bangladesh: A Far

Cry With Sustainable Development

A K M Mahmudul Haque, S M Akram Ullah, Md. Asfaq Salehin

\section{ACKNOWLEDGEMENT}

The research was funded jointly by the University Grants Commission of Bangladesh and the University of Rajshahi, Bangladesh. We would like to give special thanks to them for providing support in research grants. Besides, we are much grateful to the study participants, the research assistants and the staff of the selected Municipalities of this research.

\section{REFERENCES}

Ahsan, A., Alamgir, M., El-Sergany, M. M., Shams, S., Rowshon, M. K., \& Daud, N. N. N. (2014). Assessment of municipal solid waste management system in a developing country. Chinese Journal of Engineering, 2014(12a), 1-11.

Alam, 0., \& Qiao, X. (2020). An in-depth review on municipal solid waste management, treatment and disposal in Bangladesh. Sustainable Cities and Society, 52, 101775.

Ashikuzzaman, M., \& Howlader, M. H. (2020). Sustainable Solid Waste Management in Bangladesh: Issues and Challenges. Sustainable Waste Management Challenges in Developing Countries, $35-55$.

Asim, M., Batool, S. A., \& Chaudhry, M. N. (2012). Scavengers and their role in the recycling of waste in Southwestern Lahore. Resources, Conservation and Recycling, 58, 152-162.

Brannen, J. (2017). Mixing methods: Qualitative and quantitative research. Routledge.

Das, S., Lee, S.-H., Kumar, P., Kim, K.-H., Lee, S. S., \& Bhattacharya, S. S. (2019). Solid waste management: Scope and the challenge of sustainability. Journal of Cleaner Production, 228, 658-678.

de Oliveira, C. R., Bernardes, A. M., \& Gerbase, A. E. (2012). Collection and recycling of electronic scrap: A worldwide overview and comparison with the Brazilian situation. Waste Management, 32(8), 1592-1610.

Desa, A., Kadir, N., \& Yusooff, F. (2012). Environmental awareness and education: A key approach to solid waste management (SWM)-A case study of a University in Malaysia. Waste Management-An Integrated Vision, 101-111.

Dey, D., Krukkert, I., \& Osse, E. (2020). Inclusion of innovative technology in integrated waste management of a city: case of Bogura, Bangladesh. Journal of Water, Sanitation and Hygiene for Development, 10(3), 608-614.

Ferronato, N., \& Torretta, V. (2019). Waste mismanagement in developing countries: A review of global issues. International Journal of Environmental Research and Public Health, 16(6), 1060.

Gautam, M., \& Agrawal, M. (2021). Greenhouse Gas Emissions from Municipal Solid Waste Management: A Review of Global Scenario. Carbon Footprint Case Studies, 123-160.

Hossain, M. S., Santhanam, A., Norulaini, N. A. N., \& Omar, A. K. M. (2011). Clinical solid waste management practices and its impact on human health and environment-A review. Waste Management, 31(4), 754-766.

Islam, K. M. N. (2018). Municipal solid waste to energy generation: An approach for enhancing climate co-benefits in the urban areas of Bangladesh. Renewable and Sustainable Energy Reviews, 81, 2472-2486.

Joseph, K. (2014). Municipal solid waste management in India. In Municipal solid waste management in Asia and the Pacific Islands (pp. 113-138). Springer.

Malav, L. C., Yadav, K. K., Gupta, N., Kumar, S., Sharma, G. K., Krishnan, S., Rezania, S., Kamyab, H., Pham, Q. B., \& Yadav, S. (2020). A review on municipal solid waste as a renewable source for waste-to-energy project in India: current practices, challenges, and future opportunities. Journal of Cleaner Production, 277, 123227. 


\section{Khazanah Sosial, Vol. 3 No. 1 : 1 - 14}

Capacity of Solid Waste Management of The Municipalities in North-West Region of Bangladesh: A Far Cry With Sustainable Development

A K M Mahmudul Haque, S M Akram Ullah, Md. Asfaq Salehin

Marshall, R. E., \& Farahbakhsh, K. (2013). Systems approaches to integrated solid waste management in developing countries. Waste Management, 33(4), 988-1003.

Mishra, L. (2016). Focus group discussion in qualitative research. Techno Learn, 6(1), 1.

Ray, A. (2008). Waste management in developing Asia: can trade and cooperation help? The Journal of Environment \& Development, 17(1), 3-25.

Rodić, L., \& Wilson, D. C. (2017). Resolving governance issues to achieve priority sustainable development goals related to solid waste management in developing countries. Sustainability, $9(3), 404$.

Shekdar, A. V. (2009). Sustainable solid waste management: An integrated approach for Asian countries. Waste Management, 29(4), 1438-1448. https://doi.org/10.1016/j.wasman.2008.08.025

Sutrisno, E. (2017). The study of river pollution related to domestic waste in the perspective of community legal culture. South East Asia Journal of Contemporary Business, Economics, and Law, 12(4), 134.

Tai, J., Zhang, W., Che, Y., \& Feng, D. (2011). Municipal solid waste source-separated collection in China: A comparative analysis. Waste Management, 31(8), 1673-1682.

Wilson, D. C., Rodic, L., Cowing, M. J., Velis, C. A., Whiteman, A. D., Scheinberg, A., Vilches, R., Masterson, D., Stretz, J., \& Oelz, B. (2015). 'Wasteaware'benchmark indicators for integrated sustainable waste management in cities. Waste Management, 35, 329-342. 